\title{
CAUSES AND NATURE OF ECONOMIC AND SOCIAL CONTRADICTIONS OF THE AGRICULTURAL SECTOR IN TRANSITIONAL ECONOMIES
}

\author{
Olga SHULGA ${ }^{1}$ \\ Kyiv National Economic University named after Vadym Hetman, Ukraine
}

\begin{abstract}
Today the state of the agricultural sector in most economies in transition is disappointing and caused by unresolved social and economic contradictions in its development, which in the transformations only worsened. Therefore, to develop effective agricultural policies to address the existing contradictions in the agricultural sector, it is needed to find their nature and causes and development. This is what will resolve current contradictions and predict the natural course of development of agrarian relations in the future. The subject of the investigation - nature and causes of economic and social contradictions of the agrarian sector in transitional economies. To clarify these issues there were used methods such as dialectic, systemic and structural, analysis and synthesis, unity logical and historical approaches, induction and deduction, etc. The aim is to find out the nature of economic and social contradictions of the agricultural sector, their causes and development in transitional economies. Based on these methods, it is found that a contradiction is an internal source of development, and causes of changes and development of the contradictions are inherent within it. That means that the contradiction is a process that is changing, evolving itself, as its domestic activity and through interaction with the struggle of opposites. Accordingly, the economic and social contradictions in the development of the agricultural sector are of objective nature. Mistakes in the actions of agrarian relations do not generate new conflicts, but only reinforce the negative side of contradictions inhibiting its solution. This is due to the fact that every contradiction has its objective course of development and natural solutions through new quality reproduction with the peculiar contradictions of development. The subjective factor can only help or hinder solving contradictions, lead to a partial solution of contradictions. Errors are mostly subjective and complicate the process of identifying and resolving contradictions. Reasons for contradictions in the agricultural sector can be divided into two groups: objective (generated by the struggle of opposites) leading to the solution of contradictions of the previous system and the emergence of new contradictions inherent in the future system; objective and subjective, which because of the dominance of the subjective factor at the stage of resolving contradictions lead to the preservation of the previous system contradictions, increase their negative side, and to the emergence of problems and difficulties in resolving existing contradictions. The development of the agricultural sector is determined by imperatives (conditions and directions of action of agrarian relations), which can be divided into the following groups: social, economic, national, historical, technological, informational, cultural, international, religious, political. Development of contradictions is inextricably linked with the development of economic systems and elements of the structure. After all elements of the economic system and its structure are the opposite, being in contradiction with itself and with each other. In developing economies, as well as the development of contradictions, stages of development are taken place. There are two common stages in the development of economic systems caused by cyclicity - rising stage of development (from the emergence to the peak) and the descending phase of development (from the peak to its decay). Rising stage of the life cycle stage of the economic system includes the origin, formation stage and stage performance. The downward phase is defined by stages of destruction of an integrated economic system, collapse and disappearance. These stages of development of economic systems are in close contact with the stages, phases of contradictions. Transitions from one state to another economic system are based on the transformation processes that change the internal state of the system. Transformation processes can occur both evolutionary (accumulating changes that are in the process of transformation) and revolutionary (under the influence of subjective factors) through reforms, which are the adjustment of individual elements of the system without changing its foundations.
\end{abstract}

Key words: contradictions, agricultural sector, transformation economy, nature of contradictions, causes of contradictions, imperatives.

JEL Classification: J100, Q100, P410, A100

\footnotetext{
Corresponding author:

${ }^{1}$ Department of Political Economy, Kyiv National Economic University named after Vadym Hetman.

E-mail: shulga_olga_a@ukr.net
} 


\section{Problem and its connection with important scientific and practical tasks}

The importance of the agricultural sector in the national economy of any country is evident. It is a part of the backbone of the national economy, which ensures the development of technology-related sectors of the national economy and creates social and economic framework of rural development, the principles of food and in fixed terms of economic, environmental and energy security. However, today the state of the agricultural sector in most economies in transition is disappointing and poor. The reasons for this situation have deep roots, as related to social and economic contradictions in the development of agrarian sector, which in the transformations only worsened.

\section{Formulation of research objectives}

The purpose of the article - to clarify the nature of economic and social contradictions of the agricultural sector, their causes and development in transitional economies. This is what will resolve current contradictions and predict the natural course of development of agrarian relations in the future. In order to clarify these issues will apply techniques such as dialectic, systemic and structural, analysis and synthesis, unity logical and historical approaches, induction and deduction, etc. Disclosure and analysis of the nature of different types of social and economic contradictions will determine their nature and stages of consideration of contradictions will determine their causes and development. The study found that the imperatives determine the development of the agricultural sector in transitional economies.

\section{Analysis of recent publications on the problem}

A significant contribution to research and resolve contradictions of social and economic systems are devoted works of such scientists, as Yu. K. Zaitsev, V. S. Savchuk, O. M. Moskalenko, S. V. Mochernyi, A. A. Chukhno etc. However, the question of the nature, functions, nature and causes of social and economic contradictions agricultural sector remains almost unexplored. There are only a few articles devoted primarily to the clarification of the contradictions of ownership in the agricultural sector and contradictions of environmental policy.

\section{The presentation of the main results and their justification}

In order to explain the nature of social and economic contradictions of the agricultural sector, considered the existing scientific literature classification of contradictions. It will consider the conflict with the various parties and thus more deeply penetrate into their essence to ensure proper choice of forms, methods and ways to solve them by society.

The nature of economic and social contradictions

Most disagreements are classified according to several criteria. This is due to the fact that the contradictions that occur in different types of economic systems, with different conditions of the nature, duration. There are three main groups of social contradictions, depending on their scope, sociological, economic and so on. Sociological controversies affect the relationship between the elements of social structure. There are, for example, the contradiction between social being and social consciousness, between material production and other aspects of social life, between the base and superstructure, between society and the individual. They are defined as objective and subjective contradictions, in which one side of the object (nature, productive forces, material production), and the other - a social entity (person, class, society). Superstructure contradiction - a contradiction in policy, law, beliefs, family and domestic relations, etc., and they are subjective. However, the contradictions are always subjective, deep internal social contradictions of the objective nature, which express the contradictory specific objective reality. Thus, the policy is subjective, but also objective, because it depends on the level of economic and social spheres. It is based on the contradiction between the objective requirement to improve living standards and achieve this objective inability due to the lack of material conditions for such alignment at some stage of social development.

Regarding economic contradictions, they are divided into two main groups: general and specific. General are those that characterized all socioeconomic formations (such as the contradiction between use value and cost between concrete labour and abstract labour, etc.). However, they occur because of the specific contradictions. This is illustrated by the evolution of forms of value.

There are several classifications of specific economic contradictions. In particular, depending on the nature and the essential role conflicts - the essential and neatness, required and optional, initial and nonessential; its significance - major and minor, major and other, indigenous and non-indigenous; systemic symptom: system and non-system; depending on the systemic or non-systemic nature, objective or subjective conditionality of historical development of society the contradictions of growth, or brake, of progress or regress; focus on contradictions ascending or descending development; on spheres of manifestation in society - the contradictions in the sphere of economic, social, political, spiritual (ideological) life; volume of coverage of contradiction - inclusive (which appear in society as a whole) and partial (which manifest themselves in certain spheres of public life); the amount of historical actions - those that occur in all socio- 
economic formations, in a number of socio-economic formations (antagonistic or non-antagonistic), in one formation (formation, general informational), and in relation to the communist socio-economic formation a phase (socialism or communism) this formation or both; on genetic grounds - new and old; permanently permanent and temporary: periodic (acting in a particular period), short-term, the contradictions large, medium, small and of short duration; depending on functional roles - major and private; the nature of the ties on phase and interphase; from the self-antagonistic and nonantagonistic; related to this phenomenon internal and external; from the origin on the objective and subjective, necessary and accidental; by territorial coverage - at the national and international etc. (Arroyo; Semenov).

Of course, this classification is conditional, because the same contradiction can be attributed to different groups. However, it has important methodological significance in the study of contradictions, because it allows performing the same contradictions with the various parties and thereby more in-depth exploring the dialectics of social development.

According to the above classification, the contradictions that are inevitable, obligatory, and act as a source of self-development of all things defined as essential. All the others that are not inevitable, obligatory, and not objectively inherent in the phenomena and processes both internal sources, the driving forces of their self-development are non-essential. Nests contradictions, according to the scientists, are created by the weakness in the organization and management of the various branches of the economy and require timely decisions.

At the same time, essential and nests, compulsory and optional, contradictions serve as the source and nonessential, because the contradiction is not only a source but also the main driving force of self-development companies. However, not all manifestations of contradictions, according to scientists, are the source and driving force of self-development companies. In these economic contradictions and forms of their manifestation they include, for example, those caused by failures of optimal proportions in the national economy, the shortcomings in the system of material incentives for workers, such phenomena as speculation, theft of state property; in the sphere of social relations is the contradiction engendered by bureaucracy, violations of legal norms and democratic standards, the national or religious hatred, etc.

Importance of the contradictions is divided into core and non-core, principal and non-principal. The basic contradiction is always the same and plays a crucial role among all the other contradictions, as the most deeply reveals the nature of social system, determines its characteristics on all phases and stages of development, explains the content and direction of its development, and has a dominant function in relation to other contradictions. The main economic contradiction refers to the individual phases or stages of development of a society on which its development is crucial. For private contradictions, it can develop into the main depending on the conditions in which society develops.

Systems of symptoms of the contradictions are divided into the systematic (inherent in the economic system) and non-systemic (transient, residual, introduced, alien). The separation of the contradictions in phase and interphase occurs horizontally and vertically. For example, social reproduction sequentially passes through four main phases: production, distribution, exchange and consumption. At these phases and between them there are contradictions, the solution of which promotes the development of each phase and the transition from one to the other.

Economic contradictions inherent in socialism are non-initial since the economic basis of the relations of production under socialism is the public ownership of the means of production. The solution of such contradictions does not require a violent, revolutionary destruction of one of the opposite sides. Antagonistic contradictions are characteristic for the different stages of the development of capitalism and in the transition from capitalism to socialism.

Division of contradictions are internal and external, associated, usually, with the state-national borders. Internal contradictions are those that take place within individual countries (or systems), and this contradiction between the individual country (system) and other states (or systems).

The origin of the contradictions is divided into objective and subjective, necessary and accidental. Subjective, random contradictions are the contradictions generated by the activity subject and basically have casual character. These contradictions may not occur, because they are the result of errors of management subject, which is not taken into account in the management of the requirements of economic laws. Therefore, according to the scientists, such contradictions are not necessary for the development of the economy and not have an objective character for society. Relatively objective contradictions, they are generated by the action of economic laws and are necessary for the further development of the economy.

In our opinion, there is inappropriate allocation of non-essential, optional, non-initial and subjective contradictions. First, because of the contradictions inherent in all phenomena and processes, they cannot be non-initial. Secondly, all the contradictions in the result and in the process of their struggle of opposites, is the source and driving force of development, therefore they are output. The examples of contradictions that are as non-essential is the result of equating the negative side of the contradiction, the growth of the epidemic (which is perceived as a brake on development) by contradiction 
in general. Otherwise, then you need to assume that social development is caused by external factors. But in this case, we will come to the conclusion that if you eliminate the action of an external factor, then it should stop development. And it is nonsense from the point of view of dialectics, since the development of matter is continuous and infinite. Thirdly, despite the fact that without the consciousness and activity of the subject is impossible to identify and to resolve the contradiction, we must not forget that at first the controversy was objectively inherent in the phenomenon or process, regardless of the will or wishes of the people. Objectivity existing in the society, economic laws and regularities and is caused by the fact that their inner source and driving force is inherent in the contradictions, which are objective. Through their decisions and appearance in public laws, there is social development. So they can't be optional or subjective. Errors in the actions of subjects, as we noted above, does not give rise to new contradictions, and only reinforce the negative side of the contradiction, hindering its solution. This is because each contradiction has its own objective and reasonable solution through the reproduction of a new quality with its inherent contradictions of development. The subjective factor, in particular, the level of consciousness, organization of social groups, competence of leading cadres, can only promote or inhibit the resolution of conflicts, lead to a partial resolution of the contradiction.

The allocation of scientists group of subjective contradictions and justification of their subjective nature may be caused, in our opinion, not only by formal-logical approach to the knowledge of the nature and causes of the controversy, but the dominant idea of the scientists of the period of socialism that under socialism no conflict of opposites, because the interests of the classes in terms of public ownership of the means of production are the same, that is, there is a unity of interests. Accordingly, the conflict is seen as something accidental, temporary, transitory, caused by errors and failures of control subjects, or are remnants of the previous economic system. Therefore, such contradictions being generated by external subjective factor may be deliberately, systematically overcome.

However, in this formulation of the question was not considered that the unity of opposites is relative, and does not exclude contradiction. But the lack of struggle of opposites, which is the absolute excludes, its cause. So it had to go, first, about the absence under socialism antagonistic contradictions, and not contradictions at all, and, secondly, it is not always taken into account the fact that internal contradictions are the source of all selfdevelopment and self-movement, not external, caused by mistakes in management.

In addition, as you can see, under socialism, the contradictions often associated with antagonism. However, such attitude is improper. Though, because of antagonistic or antagonistic opposite sides depends on the nature of ownership as the economic basis of society. In this regard, the antagonism between the opposing sides may disappear, and contradiction as the inner source of all motion and development, cannot disappear, for there will stop the movement and development.

However, to more clearly and more deeply distinguish between these concepts, it is necessary to disclose the content and essence of the contradictions that underlie the antagonism and determine it is a form of existence of the struggle of opposites.

Antagonism is a universal form of struggle of opposites, which corresponds to a form of unity, which is a combination of positive and negative opposites. Opposites, each of which tries to preserve the existing conflict, are inherently positive. Their struggle corresponds to the positive unity of opposites. Opposites, each of which tries to resolve the existing conflict is inherentlynegative. Theirstruggle corresponds to a negative unity of opposites. While antagonism of the resolution of the contradiction becomes possible only when the negative contrast dominates over the positive. Thus, the antagonism is due to the nature of those contradictions, in which the leading, defining aspect is the root, the polar difference and discrepancy (Sukhanov, 1976).

Social antagonisms appear with the emergence of mankind. In a primitive society - this antagonism is between people, clans, tribes, unions of tribes. In slave, feudal and capitalist societies where there is private property and exploitation of man by man, there is a new form of social antagonism, which is called the class. Characterized by polar opposite interests of social classes, political parties, etc. it is a fundamental mismatch of interests leads to class struggle and determines the class nature of this struggle. The content of class antagonism lies in the fact that the actions of one class are aimed at the preservation of existing contradictions, and other class - at their decisions.

On the basis of class antagonisms, there are other types of antagonisms, such as competition, rivalry, social struggle, social and labour conflicts, etc. At the same time, class antagonisms related to individual antagonisms, which in capitalist societies is one of the forms of manifestation of class antagonisms. This is because each person in a class society, is a representative of a particular class, and therefore has a class.

It may seem that class antagonism is a historical phenomenon, which arises or exists in a capitalist society, but disappears under socialism, through the solution of class antagonism between the bourgeoisie and the proletariat as the result of class struggle and socialist revolution. At the same time, keep in mind that not every contradiction under capitalism leads to class antagonisms. For example, the contradiction between technique and science (the technical training requirements of scientific and technological progress) 
leads to the development of public relations, but it does not give rise to social antagonism.

From this it follows that if opposites express the internal contradictions of the essential condition of some phenomenon, the antagonism expresses that arose on the basis of such a conflict (the confrontation of opposing social classes, political forces, etc.). That is, the antagonism is an external form, a concrete historical manifestation of the contradictions in the mode of production. Thus, the internal dialectical contradiction takes the form of external social antagonism.

At the same time, under socialism, there persist individual antagonisms, which are based on contradictions, the main side of which is a mismatch between interests of individuals between themselves and discrepancy of interests of individuals and interests of society (individualism, selfishness, drunkenness, theft of state property). Such people resist the establishment of a new and thus come into conflict with people who drive in life something new.

The most acute form of antagonism is the conflict, which is an acute condition of the struggle of opposites. This form is mainly characteristic for social antagonisms - class, group or individual.

From the above we can draw the following conclusions. First, antagonism is social in nature and manifests itself as a form of development of social production; second, it has a historically transitory character; third, social antagonism is a narrower concept than social conflict (the latter, in addition to opposition and confrontation of social classes, includes also relations of cooperation or alliance between them); fourth, between contradiction and social antagonism, there is a relationship of intrinsic and derived, internal reason, and social consequences (Semenov, 1987).

Given the relationship of the contradictions antagonisms, V.I.Sukhanovgives the following definition of the concept of antagonistic economic contradiction the contradiction in which leading, defining aspect is fundamental, polar opposites' mismatch that causes opposites to clash, conflict. On the antagonistic social contradictions in society, it is the defining aspect, a fundamental mismatch, incompatibility of interests of social opposites (Sukhanov, 1976).

However, antagonism is not the only form of struggle of opposites. The society also has a struggle of a special sort, which promotes mutual support in the implementation required to store each of opposite changes and conditions. It is non-adversarial in nature, because when this struggle is the alliance of opposites' activities into a single activity aimed at the preservation or resolution of contradictions. At the heart of this struggle are the contradictions in which the leading side is defining the indigenous identity, the matching of opposites. Indigenous identity is the impetus that prompts for a joint struggle, provides a further saving of opposites, leads to the qualitative changes that will approach them in the future, in the new system.
As mentioned above, in addition to antagonistic economic contradictions, there are also nonantagonistic in which leading, defining aspect is the indigenous identity, matching opposites, which lead to joint, complementary struggle. In the non-adversarial social conflicts, leading, defining aspect is fundamental conformity, compatibility of interests of social opposites (Sukhanov, 1976).

However, nonantagonistic contradictions can be played on the basis of the antagonistic contradictions, and vice versa. For example, the interests of employees of agricultural enterprises and enterprises of other industries in many respects similar, so the contradiction between them is non-initial. However, as the aggravation of social contradictions between the city and the village, nonantagonistic contradictions can become antagonistic. Therefore, it is necessary to joint action of the parties to social cohesion, aimed at solving the existing contradictions between them. Such actions under socialism were implemented in the form of aid, mutual aid and cooperation. Today, these actions can be implemented through the creation of clusters or in the form of social partnership (for example, to attract employees to the management, employee ownership part of the company shares and the like).

Based on the analysis of the nature of antagonistic and non-antagonistic contradictions, it follows that the development of the agricultural sector is caused by struggle of opposites, which give rise to cause controversy. In the process and on the basis of the struggle of opposites it is the development of contradictions, in which the modified unity and there is a transition from one form of existence of matter to another. It follows that contradiction, being internal to the active state of all things, accompany all things during the whole period of its existence. That is, they are objective and universal.

However, despite this, the scientific literature argued that some contradictions, though, are subjective in nature and for subjective reasons. An example of such contradictions leads to contradictions arising from noncompliance with requirements of economic laws and mistakes of management subjects. However, practice shows that this position is wrong.

It is quite often in the history of the development of economic systems that there are the subjects of agrarian relations not having sufficient information about the nature of contradictions, conditions, methods and ways of their solution, spontaneously directed actions to resolve most conflicts, and only a negative side. And since these negative effects manifested through the activity of individuals, social groups, political parties, the impression was that with the "elimination" of these subjects it will be held on the controversy. Evidence of this is the uprising, revolutions and political upheavals.

Similar errors in the resolution of contradictions can be observed in conditions of administrative-command economic system, when the resolution occurs not 
spontaneously, but systematically, deliberately. Under these conditions, the actions of the subject of management, which may incorrectly determine the nature, stage of development of the contradictions or methods of its solution, can lead to an exacerbation of contradictions, and discrepancies are identified not by the essence and content. And in the case when it was a social conflict, it can escalate with nonantagonistic in antagonistic.

That is, the notion of "contradiction" is associated with such concepts as "problems" and "difficulties", believing that contradictions are a result of their accumulation in the socio-economic development of the country. Therefore, it is important to figure out how interrelated contradictions correlate with the emerging problems and difficulties.

Usually, there are problems or the result of errors of the administrative apparatus during the implementation of the objective laws of social development, or because some questions were not timely, the decision (concealed, concealment). However, the presence of problems can be a sign, at the same time, the actions of the internal contradictions that were not timely, and led to negative trends in the development of certain industries or the national economy as a whole. In this case, a problem is an indication that the controversy is "ripe" and must be addressed. That is, the problems can have both subjective and objective nature.

As for difficulties, it is most disappointing situations, in which you have to solve problems or resolve conflicts. For example, the strengthening of the military threat leads to the diversion of significant financial, human and other resources to protect national borders. And it diverts funds, for example, from the technical and technological modernization of agricultural enterprises. However, the difficulties can be a result of the not entirely successful solution of the problems or solutions in general, the result of which may cause a crisis situation (for the purpose of saving budget funds for the maintenance of rural schools was conducted by their Union, which led to a loss of some villages).

Thus, between the contradictions, problems, difficulties, and error patterns emerge. Some of the problems and difficulties reflect the effect of the existing internal contradictions that have not been a timely decision. However, they are only one of the forms of development of the contradictions, and cannot fully reflect their essence. Concerning mistakes, they are predominantly subjective and complicate the process of identifying and resolving contradictions.

The position of the scholars about the subjective nature of the contradictions can also be related to the fact that the opposite sides of the contradiction manifests itself in the contrast of indigenous objective interests of the social groups concerned, and then translated in their purposeful actions. However, it does not take into account the fact that economic interests and economic needs, economic incentives exist for people as an objective reality and determine their actions. But, like all economic processes, they manifest themselves through the minds of people.

According to this individual, the subject of management through its practical activities do not generate controversy, but only reinforce or weaken the negative direction until the contradiction is resolved. "The subjective factor can only modify the manifestation of the essence of the law of unity and struggle of opposites, however, cannot change the objective essence" (Sukhanov, 1976).

For example, considered the contradiction between production and consumption, a form of manifestation which is, for example, the crisis of underproduction. Under the influence of scientific and technical progress and the growth of technological capabilities, the crisis of underproduction can be overcome, and the contradiction resolved. As you can see, the subjective factor (the development of technological capabilities influenced the development of science and technology) within a certain period of time weakens the negative side of the contradiction, yet a contradiction, which manifested itself in the form of a crisis of underproduction, was solved through the transition to another form, such as the crisis of overproduction.

It follows from this that contradiction is an internal source of development, and the causes, changes and development of the contradictions inherent in it. These causes can be determined by considering the stage of development of the contradiction (Sukhanov, 1976).

The causes of the economic and social contradictions

Theinitialstagein the development of the contradiction is the stage of the formation of contradictions. Aspect ratio at this stage is characterized by insignificant difference, mismatch and indigenous identity opposite sides. This insignificant difference may be due to the nature of the opposites, and to be transient, external or random factors. As the contradiction at this stage contains a contrast, it is expressed as the ratio between external opposites.

Indigenous identity and unimportant difference cause the unity and struggle of positive opposites, which mutually stimulate each other. The positive unity of opposites leads to the lack of clear boundaries that divide the opposites, and the difference is only in the concrete form of unity. In its outward manifestation the opposites are not assigned to certain phenomena, and easily pass into one another, but they differ from internal opposites, not the same with them. Because the inner opposites reflect the nature, and the external phenomenon; the internal opposites are in one phenomenon, and different phenomena.

Aspect ratio at this stage stimulates the contrary to the joint fight, which can be a struggle of positive and negative opposites. However, such a fight combined with external factors leads to the fact that each the opposite of the 
growth differences become more defined and isolated. Transformation of identity in difference, the compliance mismatch leads to a change in aspect ratio. The difference, the discrepancy becomes more significant, then polar, and identity is irrelevant. As a result, the development is entering a stage of exacerbation.

In the acute stage there is a further transformation of identity in difference, the growing differences of quantitative changes that lead to the buildup of qualitative change, qualitative discrepancies. The number of differences increases, there are new differences. These incremental differences are caused by changes in each contrary, movement of the inconsistencies in their interaction and struggle of opposites. Quantitative and qualitative changes in identity lead to changes in it, with the result that the difference between the opposing sides has only increased. It is possible to trace the evolution of the productive forces and private ownership at different stages of the development of capitalism.

In the acute stage of contradiction, the unity and struggle of opposites, positive and unity and struggle of opposites, the negative turns into such a unity and struggle of opposites, where one of them is a positive contrast in relation to the current, and the second becomes negative in the opposite, denying existing.

Since the exacerbation of the contradictions is accompanied by the increase of differences and inconsistencies, there is a separation of opposites that is their polarization. The inner unity of opposites becomes the external unity of opposites, an internal conflict becomes external. The emergence of negative opposites on the outer-level contradictions leads to the emergence and strengthening of the struggle of opposites. Depending on them side opposites (positive or negative) will have an advantage, this will lead to either exacerbation of the disease or weakening of the trend. Usually, the resolution of the contradiction occurs when negative opposite is dominant.

The acute phase is not mandatory for all differences. It occurs only in those contradictions, which develop gradually, because without the presence of the negative counterpart and its dominance over the positive they can't be resolved (because a negative opposite occurs and is formed only in the process of aggravation of contradictions) (Sukhanov, 1976).

Thus, with the transition from the phase of the formation of the contradictions into a phase of exacerbation there is a transition of the internal contradictions in the outdoor. Essence is divided into polar separated relative to each other opposites. In addition, if the phase of the formation of contradictions dominated by self-assertion and mutual approval of the opposites, the acute phase is dominated by their selfdenial and mutual rejection (Sukhanov, 1976).

In the phase of resolution of conflicts there is the transformation of external contradictions in a qualitatively new internal inconsistency that is a process of "convergence" (the formation of a new unity) of opposites through their struggle, which is resulted in the one opposite transforming into something else. Thus, there are two forms of motion of the contradictions at the stage of decision - time and gradual "fusion" of opposites. If there is a "merge" of separate, polar opposites, it looks like a single act, and if the convergence of opposites takes place in the trend, then there is a gradual "merger" of opposites. In addition, with the gradual solution of the contradictions it can be identified in each stage of their partial stages of dispute resolution.

From the latter it follows that in the development and resolution of conflicts, especially social, a significant role is played by the subjective factor, which actions can both accelerate and hinder the development and resolution of contradictions. However, the fact that resolution of conflicts by reproducing on the basis of its other contradictions does not mean the subjective nature of its occurrence. After the appearance, formation, escalation and resolution of contradictions there is a consistent change of its occurrence, negation and negation of negation, which form a cycle in the movement of contradictions. The final phase of the development cycle of contradiction is the initial phase of the next cycle of development of the contradictions.

As it is mentioned above, depending on the value in the development of the contradictions of objective and subjective factors, the reasons of contradictions of the agricultural sector can be divided into two groups:

1) objective (generated by the struggle of opposites), leading to resolution of differences between the previous system and the emergence of new contradictions inherent in the future system;

2) objective-subjective, which through the dominance of the subjective factor at the stage of conflict resolution lead to the preservation of the contradictions of the previous system, increase their negative aspects and the problems and difficulties in their solution.

\section{The imperatives of development}

\section{of agrarian sector of economy}

Since contradictions are the driving force of development, and the development gives rise to new contradictions, it is important to find out what affects the development of the agricultural sector, the logic of activity of subjects of agrarian relations. One of the components of the description of actions of subjects of agrarian relations is the imperative. The imperative is a statement that describes the schema of human behaviour; using the imperative subject that proclaims, trying to impose a certain action to another entity. An important component of the imperative is the appeal to norms and possible consequences of the performance (reward) or failure (punishment), a particular action (Arutyunov, 2005). That is, the imperatives define the conditions and directions of development of the agricultural sector that give rise to such development of contradictions. 
You can select these groups of imperatives:

1) social (social status of people - free or dependent, working conditions, living conditions of people). For example, the feudal mode of production, which was based on the dependence of peasants from the landowner, for their non-economic coercion to work, causes low productivity of the serfs and the development of agricultural production on an extensive basis;

2) economic (action of economic laws; laws of development of agrarian relations - the concentration, the specialization of production; the availability of land, water resources, climatic conditions, topography, manpower, education and training of employees; development of related agricultural industries; level of economic development of the country, dominant technological mode of production, form of ownership, nature of land use and the like). For example, in economically developed countries farming is dominated, which is conducted on advanced technical database, and the developed countries dominate by crop and extensive livestock production that takes an advantage of pastures and little connected with other branches of agriculture. In tropical Africa and the island territories of Oceania is dominated by prefeudal ways, communal land tenure, and in South-East Asia - landlord economy sheikhs in South America - plantain economy (the large estates, the latifundia);

3) technology (level of technical equipment, level of chemicals, introduction of achievements of agricultural science in production, and the like). For example, the use of multifunctional machinery and agricultural production with genetically modified organisms in developed countries, and the use of morally and physically worn-out equipment and actually manufacture environmentally friendly products in Ukraine, but in a much smaller quantity;

4) information (dissemination of information about new technologies for agriculture, processing of agricultural products, agricultural production, etc., that allows countries who are developing these technologies and countries that have the means to get "information" about these technologies to increase production of agricultural products);

5) international (participation in the international division of labour, international trade, etc., which leads to the specialization of countries in the cultivation of one or more types of agricultural products). For example, the Netherlands - meat-dairy products Brazil - coffee, China - rice, Ukraine - grain etc.;

6) historical (the historical destiny of self-government, colony or island country, geographical location, etc.). For example, Japan, Russia sells fish and fish production, and Asian States are engaged in agriculture;

7) political (agrarian policy of the government in relation to the vision of the place and role of the agricultural sector in the national economy). For example, collectivization in the Soviet Union or the policy of supporting prices and farmers' incomes in the EU;

8) national (the spirit of the nation, its patriotism, mindset and the like). For example, the spread of KubSU in China and family (individual) farms in Western Europe;

9) cultural (lifestyle, traditions of farming, level of tilled soil, etc.). In the historical past in Russia a communal land ownership dominated, and in Ukraine - household; high levels of tilled soil in Asia, North America, Ukraine; 10) religious (the spread of a particular religion). Islam forbids eating pork and Hindus to kill cows.

The development of contradictions is inextricably linked with the development of economic systems and elements of their structure because all the elements of the economic system and its structure represent opposites, at odds with themselves and their others. In the development of economic systems, as in the development of contradictions, is the place the stages of their development. There are two general stages in the development of economic systems, due to the cyclical nature, the rising stage of development (from inception to the peak of development) and the stage of development of descending (from its peak to its collapse). The rising phase of the life cycle of the economic system includes the stage of emergence, the stage of formation and operation phase. The downward phase is determined by the stages of destruction of the whole economic system, the disintegration and disappearance.

Throughout the history of mankind constantly undergoing transitions from one economic system to another, when one system is at the formative stage, another is at the stage of collapse. Such transitions occur on the basis of the transformation processes that change the internal state of the system. Transformation processes can occur both evolutionary (accumulating changes that occur in transformation processes) and revolutionary (under the influence of the subjective factor) through reforms, which are a process of adjusting individual elements of the system without changing its foundations.

These stages of development of economic systems are in close connection with the stages, phases of development of a conflict, as the emergence of an economic system means the solution of certain existing contradictions, the existing gap of the unity of opposites through their struggle, and the emergence of new contradictions, the transition to a new unity of opposites, and consequently to a new higher level, on a more perfect basis.

System that occurs at the first stage of its development has a considerable potential of its accelerated development, the implementation of which depends on several points. First, the speed of solving the contradictions of the previous economic system. The sooner they are resolved, the faster will be the 
development of a new economic system and qualitative changes in it ("shock therapy" in Poland). Secondly, the contradictions that arise together with the new economic system are the source of its development. Thirdly, the intensity of development of the economic system external factors (other systems), whose influence can be both positive and negative (for example, liberalization of prices and trade for the development of the agricultural sector and the economy as a whole). In addition, the intensity of development of the economic system on the upward stage of its development is expressed in the accumulation of quantitative changes lead to qualitative changes. However, qualitative changes keep quantitative changes, resulting in the development of the economic system going into a downward phase.

On the descending stage stand external against each other opposites that have a common basis. The aggravation of contradictions between the existing quality and quantitative changes leads to a slow process of development of economic system, qualitative changes occurring on the basis of another system. The result is a transition to the new system (Sukhanov, 1976).

Thus, during the whole period of existence of the economic system during the movement of its contradictions, there are changes in all its subsystems, components and elements. Each of these components of the system is self-contradictory, which leads to quantitative and qualitative changes in the system components and their structures. These changes lead to the emergence of new elements and new elements (for example, instead of collective and state farms having economic companies, rental companies, etc.) who exercise influence on their connections and relationships, i.e. there are new relationships between elements (there are intermediary structures, now on a contractual basis, there is the supply of resources, equipment from the raw agro-industries, etc.). Changes in the connections between the elements affect the elements themselves. However, depending on what it changes and what is their nature, the impact can be both negative and positive. Therefore, the development of the contradictions of the system is the source of development of the system itself and all its structural elements.

\section{Conclusions and prospects for further research}

Despite the fact that the unconscious activity of the subject is impossible to identify and to resolve the contradiction, we must not forget that all social and economic contradictions objectively inherent in the phenomena and processes. That is, the contradictions are objective. Errors in the actions of subjects do not produce new contradictions, and only reinforce the negative side of the contradiction, hindering its solution. This is because each contradiction has its own objective and reasonable solution through the reproduction of a new quality with its inherent contradictions of development. The subjective factor can only promote or inhibit the resolution of conflicts, lead to a partial resolution of the contradiction.

The reasons of contradictions in the agricultural sector can be divided into two groups depending on the values in the process of development of objective and subjective factors: objective (generated by the struggle of opposites) that lead to the resolution of the contradictions of the previous one and to the emergence of new contradictions, which are characteristic of the future system; objectivesubjective, which through the dominance of the subjective factor at the stage of conflict resolution lead to the preservation of the contradictions of the previous system, increase their negative side and the problems and difficulties in resolving existing disputes.

One of the components of the description of actions of subjects of agrarian relations is the imperatives that define the conditions and directions of development of the agricultural sector, and generate contradictions for such development. You can select these groups of imperatives: social, economic, information, technological, religious, cultural, political, national, historical, international. Further research in this direction will address to clarify the contradictions in different types of economic systems.

\section{References}

Arroyo, Zh. (1984). Economic contradictions under socialism. Essence, manifestation, resolution - Moscow, Polytyzdat, 223 p.

Arutyunov, V. Kh., Mishyn, V. M., Svintsitskyi, V. M. (2005). The methodology of the socio-economic knowledge Kiev, KNEU, 353 p.

Dudel, S. P., Shtraks, H. M. (1967). The law of unity and struggle of opposites - Moscow, "Visshaia shkola”, 248 p.

Sabluk, P. T. (2011). Organizational and economic modernization of the agricultural sector: scientific report Kiev, NNTS IAE, $342 \mathrm{p}$.

Semenov, V. S. (1987). The dialectics of socialism - Moscow, “Misl”, 429 p, [1] p.

Sukhanov, V. Y. (1976). Item contradiction, its structure and mechanism of action - Saratov, Yzd-vo Saratovskogo unyversyteta, $167 \mathrm{p}$. 


\section{Ольга ШУЛьгА}

\section{ПРИЧИНЫ И ПРИРОДА ЭКОНОМИЧЕСКИХ И СОЦИАЛЬНЫХ ПРОТИВОРЕЧИЙ АГРАРНОГО СЕКТОРА В ТРАНСФОРМАЦИОННЫХ ЭКОНОМИКАХ}

Аннотация. На сегодня состояние развития аграрного сектора в большинстве трансформационных экономиках является неутешительным, и обусловлено нерешенными социальными и экономическими противоречиями в его развитии, которые в условиях трансформационных преобразований лишь обострились. Поэтому, чтобы разработать эффективную аграрную политику по решению существующих в аграрном секторе противоречий, необходимо выяснить их природу и причины возникновения и развития. Именно это позволит разрешить нынешние противоречия и спрогнозировать закономерный ход развития аграрных отношений на перспективу. Предмет исследования - природа и причины экономических и социальных противоречий аграрного сектора в трансформационных экономиках. Для выяснения этих вопросов были применены такие методы, как диалектический, системно-структурный, анализа и синтеза, единства логического и историческогоподходов, индукции и дедукции и другие. Цельисследования-выяснить природу экономических и социальных противоречий аграрного сектора, их причины возникновения и развития в трансформационных экономиках. На основе этих методов удалось установить, что противоречие является внутренним источником развития, и причины возникновения, изменения и развития противоречия заложены в нем самом. То есть противоречие является процессом, который меняется, развивается сам по себе, в меру своей внутренней активности и через взаимодействие с борьбой противоположностей. В соответствии с этим, экономические и социальные противоречия в развитии аграрного сектора имеют объективную природу. Ошибки же в действиях субъектов аграрных отношений не порождают новых противоречий, а лишь усиливают негативную сторону противоречия, тормозящие ее решение. Это обусловлено тем, что каждое противоречие имеетсвойобъективныйходразвитияизакономерноерешениечерезвоспроизведениянового качества с присущими ей противоречиями развития. Субъективный фактор может лишь способствовать или тормозить разрешения противоречия, вести к частичному разрешению противоречия. Ошибки имеют преимущественно субъективный характер, и усложняют процесс выявления и разрешения противоречий. Причины противоречий в аграрном секторе можно разделить на две группы: объективные (порождены борьбой противоположностей), что ведут к разрешению противоречий предыдущей системы и к появлению новых противоречий, которые свойственны будущей системе; объективно-субъективные, которые через доминирование субъективного фактора на стадии разрешения противоречий, приводят к сохранению части противоречий предыдущей системы, нарастание их негативной стороны, и появления проблем и трудностей в решении существующих противоречий. Развитие аграрного сектора определяют императивы (условия и направления развития действий субъектов аграрных отношений), которые можно разделить на следующие группы: социальные, экономические, национальные, исторические, технологические, информационные, культурные, международные, религиозные, политические. Развитие противоречий неразрывно связано с развитием экономических систем и элементов их структуры. Ведь все элементы экономической системы и ее структуры представляют собой противоположности, находясь в противоречии с собой и со своим другим. В развитии экономических систем, как и в развитии противоречий, имеет место стадийность их развития. Можно выделить две общие стадии в развитии экономических систем, обусловленных цикличностью, стадию восходящего развития (от возникновения до пика развития) и стадию нисходящего развития (от пика развития до ее распада). Восходящая стадия жизненного цикла экономической системы включает стадию возникновения, стадию формирования и стадию функционирования. Нисходящая стадия определяется стадиями разрушения целостной экономической системы, распада и исчезновения. Эти стадии развития экономических систем находятся в тесной связи со стадиями, фазами развития противоречия. Переходы от одного состояния экономической системы к другому происходят на основе трансформационных процессов, которые изменяют внутреннее состояние системы. Трансформационные процессы могут происходить как эволюционно (накапливая изменения, которые проявляются в трансформационных процессах), так и революционно (под влиянием субъективного фактора) через проведение реформ, которые являются процессом корректировки отдельных элементов системы без изменения ее основ. 